\title{
Evaluation of $\Delta 2$-pioglitazone, an analogue of pioglitazone, on colon cancer cell survival: Evidence of drug treatment association with autophagy and activation of the Nrf2/Keap1 pathway
}

\author{
SOPHIE HUBER $^{1}$, SERGIO VALENTE $^{1}$, PATRICK CHAIMBAULT ${ }^{2}$ and HERVÉ SCHOHN ${ }^{1}$ \\ ${ }^{1}$ University of Lorraine, CNRS Unit 7565 - SRSMC Campus Bridoux, F-57070 Metz; ${ }^{2}$ University of Lorraine, \\ EA 4632 - Laboratory of Chemistry and Physics - A2MC, F-57078 Metz Cedex 3, France
}

Received January 15, 2014; Accepted March 6, 2014

DOI: 10.3892/ijo.2014.2408

\begin{abstract}
Thiazolidinediones have been shown to exhibit antiproliferative effects against cancer cells derived from diverse tissue origins both in vivo and in vitro. We studied the antiproliferative impact of 5-\{4-(2-(5-ethyl-pyridin-2-yl)-ethoxy)benzylidene $\}$-thiazolidine-2,4-dione ( $\Delta 2$-pioglitazone), an analogue of pioglitazone, which binds to the nuclear peroxisome proliferator activated receptor- $\gamma$ without activating it, on human adenocarcinoma-derived HT29 and HCT116 cells. In HTC116 cells, exposure to $\Delta 2$-pioglitazone reduced cell growth, but HT29 cells reached the plateau phase of growth after three days. $\Delta 2$-pioglitazone treatment did not trigger cells to enter apoptosis but enhanced the autophagy process.
\end{abstract}

Correspondence to: Dr Hervé Schohn, University of Lorraine, CNRS Unit 7565 - SRSMC Campus Bridoux, rue du Général Delestraint, F-57070 Metz, France

E-mail: herve.schohn@univ-lorraine.fr

Abbreviations: BSO, L-buthionine-(S-R) sulfoximine; CCCP, carbonyl cyanide m-chlorophenylhydrazone; DAF-2DA, 4,5-diaminofluoresceine diacetate; DCF-DA, 2'7'-dichlorofluorescein diacetate; DMEM, Dulbecco's minimum essential medium; DPBS, Dulbecco's phosphate-buffered saline; GAPDH, glyceraldehyde-3 phosphate dehydrogenase; GCL, glutamyl-cysteine ligase; GSTpi, glutathione-S-transferase pi; HO-1, heme oxygenase-1; Keap1, Kelch like-ECH-associated protein 1; NAC, N-acetyl cysteine; NQO1, NAD $(\mathrm{P}) \mathrm{H}$ dehydrogenase, quinone 1; Pio, pioglitazone, 5-\{4-(2-(5-ethyl-pyridin-2-yl)-ethoxy)-benzyl\}-thiazolidine-2,4-dione; $\Delta$ Pio, $\Delta 2$-pioglitazone, 5-\{4-(2-(5-ethyl-pyridin-2-yl)-ethoxy)-benzylidene $\}$-thiazolidine-2,4-dione; $\Delta$ PGJ2, 15-deoxy- $\Delta^{12,14}$-prostaglandin $\mathrm{J}_{2}$; MTT, (3-(4,5-dimethylthiazol-2-yl)-2,5-diphenyltetrazolium bromide; iNOS, inductive NO synthase; Nrf2, NF-2E related factor 2; PARP-1, poly(ADP-ribose) polymerase-1; PPAR $\gamma$, peroxisome proliferator-activated receptor- $\gamma$; ROS, reactive oxygen species; RNS, reactive nitrogen-derived species; Trx, thioredoxin; TZD, thiazolidinedione

Key words: $\Delta 2$-pioglitazone, pioglitazone, 15-deoxy- $\Delta^{12,14}$-prostaglandin $\mathrm{J}_{2}$, oxidative stress, $\mathrm{Nrf} 2 /$ Keap1 pathway, colon cancer
The effect of $\Delta 2$-pioglitazone treatment was related to the increase of oxygen and nitric oxide-derived species production and decreased glutathione content. Moreover, pre-treatment with an antioxidant before addition of $\Delta 2$-pioglitazone limited cell growth inhibition, reduced the production of reactive species and attenuated autophagy within the cells. The impact of the drug was associated with activation of the Nrf2/Keap1 pathway as demonstrated by the increased protein content of several antioxidant enzymes, notably heme-oxygenase-1.

\section{Introduction}

Pioglitazone (Pio) belongs to the thiazolidinedione family (TZD), a class of drugs used in the oral treatment of type 2 diabetes mellitus (Fig. 1). TZDs exert a hypoglycaemic effect by improving insulin sensitivity. These molecules act primarily by decreasing insulin resistance in adipose tissue and muscle, allowing the control of glucose metabolism by this hormone in patients (1). Pio is a potent and selective ligand of the peroxisome proliferator-activated receptor- $\gamma$ (PPAR $\gamma$ ). The transcription factor forms a heterodimer with the 9-cisretinoic acid receptor. The complexes, upon activation by each respective ligand, bind onto DNA response element localised on the promoter of PPAR $\gamma$ target genes and modulate the transcription rate of respective genes (2).

Using either cancer-derived cells from diverse origins or animal models, it has been clearly shown that TZD treatment both in vitro and in vivo leads to cell growth inhibition or tumour development arrest (2,3). However, the effects of these molecules are, in part, unrelated to PPAR $\gamma$ activation. PPAR $\gamma$-independent effects have been reported also for the prostanoid 15-deoxy- $\Delta^{12,14}$-prostaglandin $\mathrm{J}_{2}(\Delta \mathrm{PGJ} 2)$ referred to as the endogenous ligand of PPAR $\gamma$. As an example, $\triangle \mathrm{PGJ} 2$ binds to $\mathrm{I} \kappa \mathrm{B}$ inhibiting the $\mathrm{NF} \kappa \mathrm{B}$ signalling pathway (4). Several reports have demonstrated that TZD or $\triangle \mathrm{PGJ} 2$ treatment enhances the production of ROS or RNS either by PPAR $\gamma$-dependent or independent activation $(5,6)$. The production of reactive species by both mechanisms triggers cells to enter apoptosis. The production of ROS or RNS within cells induces also the activation of diverse transduction pathways, notably the NF-2E related factor $2 /$ Kelch 
like-ECH-associated protein 1 (Nrf2/Keap1) pathway (7). On the other hand, diverse anticancer drugs, mainly electrophile molecules, activate the pathway by Michaels addition on critical cysteine residues in Keap1, which disrupts the complex Nrf2/Keap1 leading to the stabilization of Nrf2. Among these molecules, $\Delta$ PGJ2, the endogenous ligand of PPAR $\gamma$, activates the Nrf2/Keap1 pathway (8).

Inhibition of cell proliferation by independent PPAR $\gamma$ activation was demonstrated using PPAR $\gamma^{-/}$mouse embryonic stem cells treated by the cognate ligand (9). Using siRNA, knockdown of PPAR $\gamma$ does not affect the ability of TZD to induce apoptotic death (6). PPAR $\gamma$ inactive analogues of TZDs were also synthesized by introducing a double bond adjoining the terminal thiazolidine-2,4-dione ring, resulting in the $\Delta 2$-analogue of the corresponding TZD. These analogues were developed in order to discriminate PPAR $\gamma$-dependent from -independent effects of TZDs since the $\triangle 2$-TZDs have no PPAR $\gamma$ activating action. Among them, $\Delta 2$-troglitazone has a similar action on prostate carcinoma cell growth as the parent molecule (10).

Herein, we evaluated the potential of $\Delta \mathrm{Pio}$ as an anticancer drug on human colon adenocarcinoma-derived colon HT29 and HCT116 cells. The results obtained were compared to those obtained with Pio. We studied the cellular modifications occurring within colorectal cells, i.e. mediated-stress cell responses after cell exposure to each drug,

\section{Materials and methods}

Chemicals. Pioglitazone was purchased from Interchim (Montluçon, France). $\triangle \mathrm{PGJ} 2$ was from Cayman Chemicals (Bertin, Montigny le Bretonneux, France). 2'-7'-dichlorofluoresceine diacetate (DCF-DA) was provided by Accros Organics (Halluin, France), acridine orange, carbonyl cyanide $\mathrm{m}$-chlorophenylhydrazone (CCCP), propidium iodide, GSH, 4,5-diaminofluorescein diacetate (DAF2-DA), orthophtalaldehyde (OPA), L-buthionine sulfoximine (BSO) and 3-(4,5-dimethylthiazol-2-yl)-2,5-diphenyltetrazolium bromide (MTT) were from Sigma-Aldrich (Saint-Quentin Fallavier France). Rabbit antibodies against caspase-3 (1087-1), GCL (5529-1), HO-1 (1922-1), NQO1 (S2173), PARP (1078-1), Beclin-1 (2026-1), lamin A/C (3770-1) were purchased from Epitomics (Euromedex, Souffelweyersheim, France). Mouse monoclonal antibodies against GAPDH (MAB374) were purchased from Millipore (Mosheim, France). Human GSTPi (F-6), human Nrf2 (H-300) and human Trx (which recognize Trx 1 and 2 isoforms; 1H6H6) antibodies were from Santa Cruz Biotechnologies (Perray en Yvelines, France). Mouse or rabbit HRP-conjugated second antibodies were purchased from Santa Cruz Technologies. RNAse A (from bovine pancreas) was from Euromedex. Other chemicals were of analytical grade.

$\Delta 2$-pioglitazone synthesis. $\Delta 2$-pioglitazone was synthesized according to the procedure of Sohda et al (11), except for the first step of condensation which was described by Deguest et al (12).

\section{Cell culture}

General conditions. HT29 and HCT116 cells were grown in Dulbecco's minimum essential medium (DMEM, Eurobio,
Courtaboeuf, France) supplemented with $10 \%(\mathrm{v} / \mathrm{v})$ heat-inactivated $\left(30 \mathrm{~min}\right.$ at $56^{\circ} \mathrm{C}$ ) fetal calf serum (Eurobio), $50 \mu \mathrm{g} / \mathrm{ml}$ gentamycin (Invitrogen, Paisley, UK) and $2 \mathrm{mM} \mathrm{L-glutamine}$ (Eurobio). Cells were maintained at $37^{\circ} \mathrm{C}$ in a humidified atmosphere in the presence of $5 \% \mathrm{CO}_{2}$. Seeding was $10^{5}$ cells/ $\mathrm{ml}$ in all experiments, with the exception of the MTT procedure. Medium was changed daily $48 \mathrm{~h}$ after seeding.

Assessment of drug cytotoxicity. $\Delta$ Pio cytotoxicity was assessed by the MTT procedure. Cells were seeded at $10^{4}$ cells/ well in 96-well plates and treated with increasing concentrations of $\Delta$ Pio $(0-100 \mu \mathrm{M})$ for $72 \mathrm{~h}$. The stock solution of $\Delta$ Pio was $50 \mathrm{mM}$ in DMSO. Dilutions of the drug were performed in DMSO prior to addition in the cell medium. Control cells were treated with $0.1 \%(\mathrm{v} / \mathrm{v})$ of DMSO, used as a molecule diluent. MTT $(0.5 \mathrm{mg} / \mathrm{ml})$ was prepared in medium containing fetal calf serum, and $100 \mu \mathrm{l} /$ well was added, and each plate was incubated for $2 \mathrm{~h}$ at $37^{\circ} \mathrm{C}$. Formazan precipitate was dissolved in DMSO and absorbance at $540 \mathrm{~nm}$ was read.

Impact of the drug on colorectal cell growth. Cell growth kinetics with $\Delta$ Pio $(50 \mu \mathrm{M})$ or Pio $(50 \mu \mathrm{M})$ were established for HT29 and HCT116 cells. Cells were seeded in 6-well plates and treated for 4 days. Control cells were treated with $0.1 \%(\mathrm{v} / \mathrm{v})$ of DMSO. Then, cells were harvested by trypsination $[0.02 \%(\mathrm{w} / \mathrm{v})$ trypsin/2 mM EDTA solution, Eurobio], and $100 \mu \mathrm{l}$ of cell suspension was mixed to an equal volume of $0.04 \%(\mathrm{v} / \mathrm{v})$ trypan blue solution prepared with Dulbecco's phosphate-buffered saline (DPBS, Eurobio) and living cells were counted using a Malassez hematometer. Cell growth was also tested with $\Delta \mathrm{Pio}$ or Pio together with $1 \mathrm{mM}$ ascorbic acid for three days. Cells were harvested and counted. Results are expressed as the ratio of treated cells versus control cells cultivated with vehicle (mitotic index).

Cell cycle distribution. HT29 or HCT116 cells were seeded in 6-well plates. Forty-eight hours after seeding, cells were exposed to each drug for $24 \mathrm{~h}$. Cell layers were washed twice with DPBS, harvested by trypsination and fixed in $70 \%$ (v/v) ethanol solution for $2 \mathrm{~h}$ and stored at $-20^{\circ} \mathrm{C}$. Cells were then centrifuged at $1,000 \mathrm{~g}$ for $5 \mathrm{~min}$ at $4^{\circ} \mathrm{C}$, washed with DPBS and centrifuged again. Pellets were suspended in $500 \mu \mathrm{l}$ DPBS containing $50 \mu \mathrm{g} / \mathrm{ml}$ propidium iodide, $20 \mu \mathrm{g} / \mathrm{ml}$ of RNAse A and $0.1 \%(\mathrm{v} / \mathrm{v})$ Triton X-100 for $20 \mathrm{~min}$ and analysed by FACS (FL2A; FACSCalibur, BD Sciences, Le Pont de Claix, France). Results were quantified using the CellQuest software (BD Sciences) and cell cycle distribution was analysed using Modfit software (Verity Software House, Topsham, ME, USA).

Clonogenic assay. Anchorage-dependent clonogenic assay was performed in 6-well plates. Cells were seeded at 1,000 cells/ well in complete medium. $\Delta$ Pio or Pio were added to cell suspensions after seeding. Cells were left to grow for 7 days. Cell clones were then washed twice with DPBS and fixed in $70 \%$ (v/v) cold-ethanol for $15 \mathrm{~min}$. They were washed twice with DPBS before adding $1 \%(\mathrm{v} / \mathrm{v})$ toluidine blue solution diluted in DPBS for $15 \mathrm{~min}$ and washed with DPBS. Images were captured with GelDoc (Bio-Rad, Marne la Coquette, France). 
Quantification of oxygen and nitric oxide-derived species. Two days after seeding, cells were treated with $\Delta$ Pio or Pio for various times up to $24 \mathrm{~h}$. Cells were loaded with $50 \mu \mathrm{M}$ DCF-DA for $15 \mathrm{~min}$ or $1 \mu \mathrm{M}$ DAF-2DA for $30 \mathrm{~min}$ at $37^{\circ} \mathrm{C}$. After incubation, cells were harvested by trypsination, washed with DPBS and finally suspended in $1 \mathrm{ml}$ of the same buffer. Fluorescence was measured in 30,000 cells/sample by flow cytometry with excitation and emission settings, at 488 and $530 / 30 \mathrm{~nm}$ (FL1). In addition, $5 \mathrm{mM} \mathrm{N}$-acetyl cysteine or $1 \mathrm{mM}$ ascorbic acid, as antioxidant, was added to the medium $1 \mathrm{~h}$ before drug treatment. Production of reactive species from mitochondria was assessed also in the presence or absence of the protonophore carbonyl cyanide m-chlorophenylhydrazone (CCCP). Cells were treated with each drug and $50 \mathrm{mM}$ $\mathrm{CCCP}$ was added for $15 \mathrm{~min}$ at $37^{\circ} \mathrm{C}$. Cells were loaded with $50 \mu \mathrm{M}$ DCF-DA for $15 \mathrm{~min}$ and they were prepared for FACS analysis. Data from control (DMSO-treated cells) and drugtreated cells were compared. Results are expressed relative to those obtained from control cells taken as 100 .

GSH content determination. Intracellular GSH levels were determined by an HPLC method described by Lenton et al (13) with slight modifications using a C18-Thermo Hypersil column (Fisher Scientific, Illkirch, France) and $1.5 \mathrm{mM}$ orthophtalaldehyde. Cells were grown in $25 \mathrm{~cm}^{2}$-flasks. Briefly, $48 \mathrm{~h}$ after seeding, cells were exposed to $50 \mu \mathrm{M}$ Pio, $50 \mu \mathrm{M} \Delta \mathrm{Pio}$ or $3 \mu \mathrm{M} \Delta \mathrm{PGJ} 2$ for various times, up to $24 \mathrm{~h}$. When used, antioxidant was added $1 \mathrm{~h}$ before drug treatment. Cell layers were washed three times with ice-cold DPBS, then suspended with $10 \%(\mathrm{v} / \mathrm{v})$ perchloric acid ice-cold solution/2 mM EDTA, $\mathrm{pH}$ 8.0. The homogenates were centrifuged at $15000 \mathrm{~g}$ for $15 \mathrm{~min}$ at $4^{\circ} \mathrm{C}$. The supernatant were stored at $-80^{\circ} \mathrm{C}$ until HPLC analysis. Perchloric acid-precipitated proteins (pellets) were solubilized in daily prepared $1 \mathrm{M} \mathrm{NaOH}$ prior to protein content determination. GSH contents were calculated as nanomole of GSH/mg of protein. Data from DMSO-treated cells (control cells) and treated cells were compared and they are expressed relative to those obtained from control cells, taken as 100 .

Western blotting. Cells were seeded in $25 \mathrm{~cm}^{2}$-flasks. Total protein homogenates were prepared from drug- and DMSOtreated cells as followed: cell layers were washed twice with ice-cold DPBS and they were scrapped with $25 \mathrm{mM}$ HEPES/ $\mathrm{KOH}, \mathrm{pH} 7.5$ containing $10 \mathrm{mM}$ EDTA, $400 \mathrm{mM} \mathrm{KCl,} \mathrm{0.5 \%}$ $(\mathrm{v} / \mathrm{v})$ Igepal, $1 \mathrm{mM}$ DTT and $0.1 \%(\mathrm{v} / \mathrm{v})$ of a protease inhibitor mixture (Sigma). Homogenates were collected and left on ice for $30 \mathrm{~min}$ before centrifugation at $15,000 \mathrm{~g}$ for $15 \mathrm{~min}$ at $4^{\circ} \mathrm{C}$. Supernatants were stored at $-80^{\circ} \mathrm{C}$ until use. Nuclear and cytoplasmic protein extracts were obtained from drug and DMSO-treated cells grown in 90-mm dishes. Cell layers were washed twice in cold DPBS and scrapped gently in DPBS. The suspension obtained was centrifuged at 1,000 $\mathrm{g}$ for $2 \mathrm{~min}$ at $4^{\circ} \mathrm{C}$. The cell pellet was mixed with an equal volume of $10 \mathrm{mM}$ HEPES/KOH, pH 7.5 containing $60 \mathrm{mM} \mathrm{KCl,} 1 \mathrm{mM}$ DTT, $0.5 \%(\mathrm{v} / \mathrm{v})$ Igepal and $0.1 \%(\mathrm{v} / \mathrm{v})$ of a protease inhibitor mixture, and left on ice for $5 \mathrm{~min}$. The sample was centrifuged at $1,000 \mathrm{~g}$ for $5 \mathrm{~min}$ at $4^{\circ} \mathrm{C}$. The supernatant, which correspond to the cytoplasmic fraction, was further centrifuged for $15 \mathrm{~min}$ at $15,000 \mathrm{~g}$ and at $4^{\circ} \mathrm{C}$ and the pellet discarded. The cyto- plasmic fractions were stored at $-80^{\circ} \mathrm{C}$. The pellet obtained after the initial centrifugation was suspended with HEPES/ $\mathrm{KOH}$ buffer without detergent and centrifuged at 8,000 g for $2 \mathrm{~min}$ at $4^{\circ} \mathrm{C}$. This step was repeated at least three times. After washing, each pellet was suspended in $25 \mathrm{mM}$ Tris- $\mathrm{HCl}$, pH 8.0 containing $600 \mathrm{mM} \mathrm{KCl}, 1 \mathrm{mM}$ DTT and $0.1 \%(\mathrm{v} / \mathrm{v})$ protease inhibitor mixture (Sigma). They were left on ice for $15 \mathrm{~min}$, vortexed every $5 \mathrm{~min}$ and then centrifuged at $15,000 \mathrm{~g}$ for $15 \mathrm{~min}$ at $4^{\circ} \mathrm{C}$. The supernatant corresponded to the nuclear fraction and each sample was stored at $-80^{\circ} \mathrm{C}$ until use.

Protein $(25 \mu \mathrm{g})$ from whole cell homogenates or $20 \mu \mathrm{g}$ of protein from nuclear or cytoplasmic fractions were resolved in 10-15\% SDS-PAGE and transferred onto PVDF membranes. The saturation step was performed in $50 \mathrm{mM}$ Tris- $\mathrm{HCl}$, $\mathrm{pH} 7.4$ containing $0.15 \mathrm{M} \mathrm{NaCl}, 5 \%$ (w/v) non-fat milk and $0.01 \%(\mathrm{v} / \mathrm{v})$ Tween-20. The antibody solutions were prepared in the same buffer and incubated overnight at $4^{\circ} \mathrm{C}$ by gentle agitation. Washing steps (3 times for $5 \mathrm{~min}$ ) were performed with $50 \mathrm{mM}$ Tris- $\mathrm{HCl}, \mathrm{pH} 7.4$ containing $0.15 \mathrm{M} \mathrm{NaCl}$ and $0.01 \%$ (v/v) Tween-20. The blots were then incubated in this buffer containing the diluted second antibody (horseradish peroxidase conjugated to goat anti-rabbit $(1: 7,500)$ or antimouse (1:7,500), Santa Cruz Technologies), and finally washed 3 times for $5 \mathrm{~min}$ with the same buffer. Blots were developed by chemiluminescence detection according to the manufacturer's protocol (Santa Cruz Technologies).

Detection of autophagy process. HT29 and HCT116 cells were seeded in 6-well plates and treated as described above for 1-3 days with daily medium changes. In parallel, HT29 cells were treated with $500 \mu \mathrm{M}$ of hydrogen peroxide used as an inducer of autophagy. Cells were incubated with $1 \mu \mathrm{g} / \mathrm{ml}$ acridine orange for $15 \mathrm{~min}$, then harvested by trypsination and suspended in DPBS before FACS analysis. Fluorescence was measured in 30,000 cells/sample, with excitation at $488 \mathrm{~nm}$ and emission settings at $670 \mathrm{~nm}$ (FL3). Results were analysed using CellQuest and Cyflogic software and they were compared to those obtained with DMSO-treated cells, taken as 1.0. In parallel, cells were treated with each drug in the presence or absence of $5 \mathrm{mM}$ NAC over three days. Total protein homogenates were prepared and western blots were performed as described, using Beclin-1 (1:1,000) and GAPDH $(1: 10,000)$ antibodies, respectively, as a marker of autophagosome formation and an internal marker for protein loading.

Statistical analyses. Differences between results from control (DMSO-treated cells) and treated cells were analysed by Student's t-test and any difference was considered significant at $\mathrm{P}<0.05$.

\section{Results}

Impact of 42-piogliatzone on human colon adenocarcinoma cell growth. In a first set of experiments, we assessed whether $\Delta$ Pio was efficient in inhibiting colon cancer-derived cell growth since the molecule had little effect on prostate carcinoma cells (10). $\Delta$ Pio cytotoxicity was estimated by the MTT procedure and the trypan blue coloration method. The $\mathrm{IC}_{50}$ was, respectively, $53.7 \pm 2.8$ and $46.2 \pm 2.4 \mu \mathrm{M}$ in HT29 and HCT116 cells. We established cell growth kinetics for 
<smiles>CN(CCOc1ccc(CC2SC(=O)NC2=O)cc1)c1ccccn1</smiles><smiles>CN(CCOc1ccc(/C=C2\SC(=O)NC2=O)cc1)c1ccccn1</smiles><smiles>CCCCC/C=C/C=C1/C(=O)C=C[C@@H]1C/C=C/CCCC(=O)O</smiles>

15-deoxy- $\Delta-12,14$ - prostaglandin $\mathrm{J} 2$

Figure 1. Structure of the molecules used in the study. $\Delta 2$-pioglitazone differs from pioglitazone by the presence of a double bound adjoining the thiazolidine-2,4-dione ring.
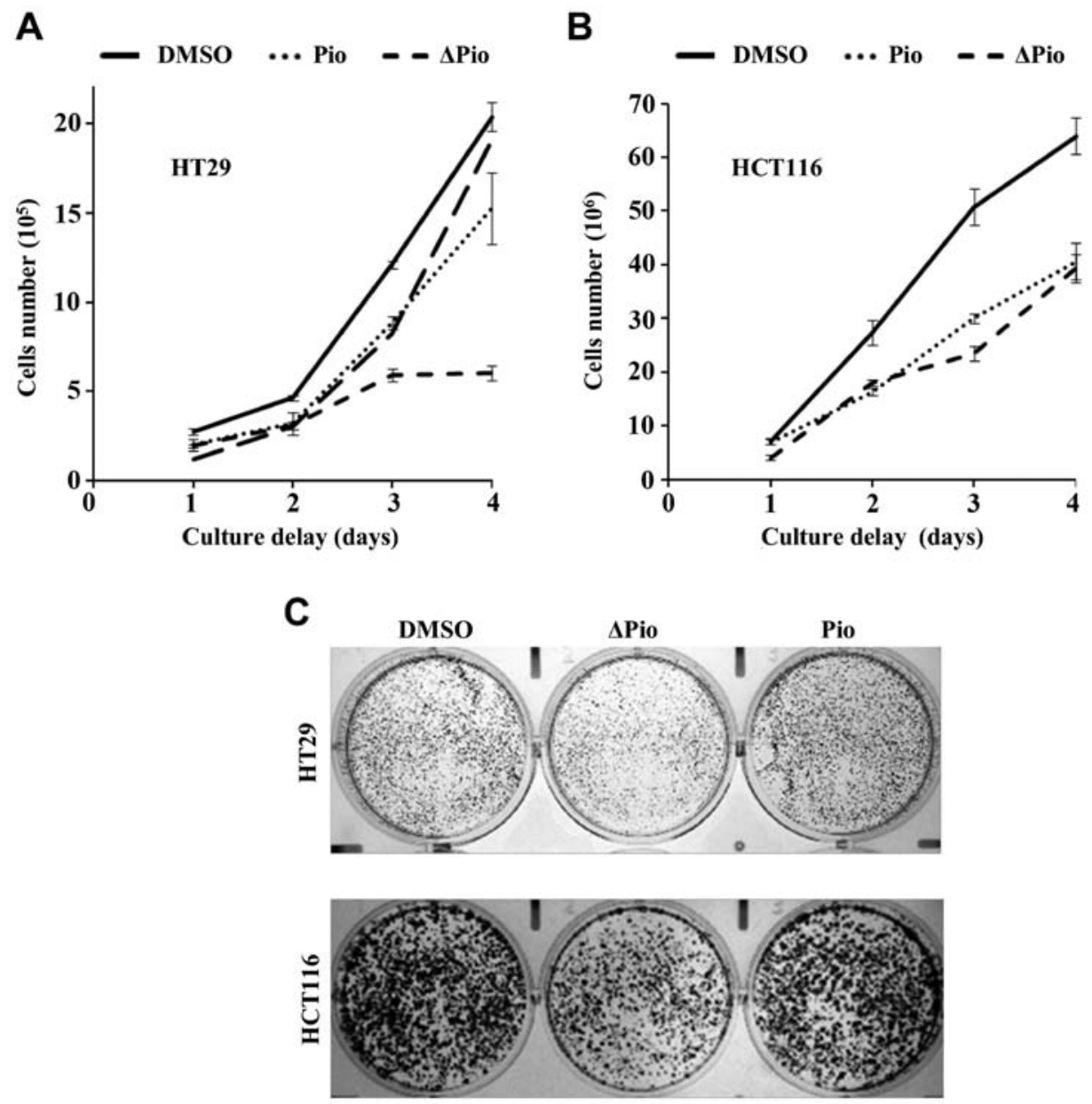

Figure 2. Cell growth kinetics with colorectal cells treated with $\Delta 2$-pioglitazone. (A and B) Colorectal cell growth curves were established for the treated HT29 (A) or HCT116 (B) cells four days after seeding. Cells were treated with $50 \mu \mathrm{M} \Delta 2$-pioglitazone ( $\Delta$ Pio) or $50 \mu \mathrm{M}$ pioglitazone (Pio). "P $<0.05$, relative to DMSO-treated cells (Student's t-test). Results are means \pm SEM of triplicate determinations from three independent experiments. (C) Anchorage-dependent clonogenic assays were performed as described in Materials and methods. The results shown represent one out of three independent experiments.

HT29 and HCT116 cells treated with $50 \mu \mathrm{M} \Delta$ Pio over four days; the results were compared to those obtained after cell exposure to $50 \mu \mathrm{M}$ Pio (Fig. 2A). HT29 cells in the presence of $\Delta$ Pio reached the plateau phase of growth after three days of treatment. In contrast, cell growth was decreased up to $35 \%$ at the end of the experiment when HT29 cells were treated in the presence of Pio (Fig. 2A). A 40\%-decrease was obtained when HCT116 cells were exposed to each molecule, but the effect of $\Delta$ Pio, previously found in HT29 cells, was not observed with these cells (Fig. 2B). Anchorage-dependent 
HT29

\begin{tabular}{|c|c|c|c|c|c|}
\hline & DMSO & $\begin{array}{c}\text { Pio } \\
50 \mu \mathrm{M}\end{array}$ & $\begin{array}{c}\Delta \text { Pio } \\
50 \mu \mathrm{M}\end{array}$ & $\begin{array}{c}\Delta \text { PGJ2 } \\
\mathbf{3} \boldsymbol{\mu M}\end{array}$ & $\begin{array}{c}\text { Cpt } \\
20 \mu M\end{array}$ \\
\hline $\begin{array}{l}\text { PARP-1 (115 kDa) } \\
\text { PARP-1 (85 kDa) }\end{array}$ & thencis & - & 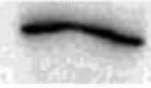 & $\longrightarrow$ & Nun \\
\hline
\end{tabular}

Caspase 3 cleaved

GAPDH
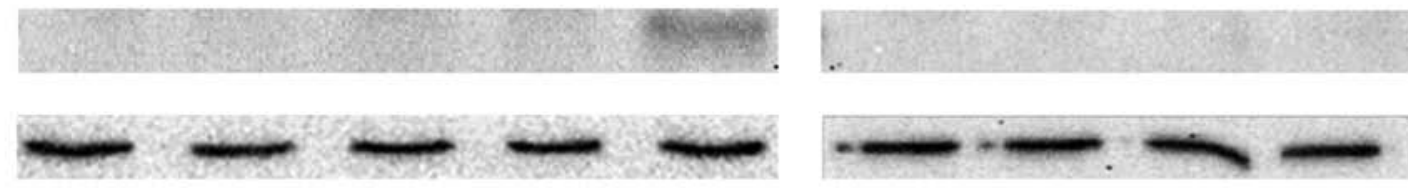

Figure 3. Effect of $\Delta 2$-pioglitazone on cell growth arrest. Western blotting was performed with protein homogenates (25 $\mu \mathrm{g})$ prepared from HT29 or HCT116 cells exposed for $48 \mathrm{~h}$ to $50 \mu \mathrm{M}$ pioglitazone (Pio), $50 \mu \mathrm{M} \Delta 2$-pioglitazone ( $\Delta$ Pio), $3 \mu \mathrm{M} 15$-deoxy- $\Delta^{12,14}$-prostaglandin $\mathrm{J}_{2}$ ( $\Delta$ PGJ2) or $0.1 \%$ (v/v) DMSO used as diluent of each drug. Blots were incubated with diluted antibodies against human PARP $(1: 1,000)$ and caspase-3 $(1: 1,000)$. Activation of caspase-3 (cleaved Casp3) and cleavage of PARP $115 / 85$ (cleaved PARP at $85 \mathrm{kDa}$ ) was achieved by exposure of HT29 cells to $20 \mu \mathrm{M}$ camptothecin for $48 \mathrm{~h}$ (Cpt), used as a positive control. Mouse anti-human GADPH antibody $(1: 10,000)$ was used as a marker of sample loading. The results represent one out of three independent experiments.

Table I. Cell distribution in cell cycle phases after 24-h drug treatment.

\begin{tabular}{llcl}
\hline Treatment & G0/G1 & $\mathrm{S}$ & $\mathrm{G} 2 / \mathrm{M}$ \\
\hline HT29 & & & \\
Control [0.1\% (v/v) DMSO] & $55.3 \pm 3.7$ & $24.0 \pm 2.9$ & $20.8 \pm 5.6$ \\
$\Delta 2$-pioglitazone $(50 \mu \mathrm{M})$ & $67.0 \pm 2.5^{\mathrm{a}}$ & $21.6 \pm 2.3$ & $11.4 \pm 3.4^{\mathrm{a}}$ \\
Pioglitazone $(50 \mu \mathrm{M})$ & $52.7 \pm 1.5$ & $29.1 \pm 2.0^{\mathrm{a}}$ & $18.1 \pm 2.6$ \\
HCT116 & & & \\
Control [0.1\% $(\mathrm{v} / \mathrm{v}) \mathrm{DMSO}]$ & $37.1 \pm 2.3$ & $30.9 \pm 0.9$ & $32.0 \pm 2.6$ \\
$\Delta 2$-pioglitazone $(50 \mu \mathrm{M})$ & $41.2 \pm 2.2^{\mathrm{a}}$ & $30.1 \pm 2.6$ & $28.6 \pm 1.5^{\mathrm{a}}$ \\
Pioglitazone $(50 \mu \mathrm{M})$ & $36.2 \pm 2.6$ & $37.4 \pm 4.6^{\mathrm{a}}$ & $26.3 \pm 4.1^{\mathrm{a}}$ \\
\hline
\end{tabular}

${ }^{\text {a }}<0.05$ relative to control cells (Student's t-test). Results are means \pm SEM of triplicate determinations from three independent experiments.

assays were performed with both cell lines (Fig. 2C) and the results obtained confirmed the higher anti-proliferative property of $\Delta$ Pio. The impact of $\Delta \mathrm{Pio}$ treatment on cell growth was associated with the alteration of cell distribution in cell cycle phases. Cell exposure to this drug resulted in cell accumulation in G0/G1-phase, whereas Pio treatment enhanced cell distribution in S-phase (Table I). However, HT29 or HCT116 cell growth arrests were not associated with apoptosis cell death. As shown in Fig. 3, neither caspase-3 activation nor PARP-1 cleavage was found in protein homogenates prepared from $\triangle \mathrm{Pio}$ or Pio-treated cells. In contrast, protein cleavage was obtained when HT29 cells were treated for two days in the presence of $20 \mu \mathrm{M}$ camptothecin used as an inducer of apoptosis.

Reactive species production and GSH depletion in $\Delta 2$-pioglitazone treated cells. Several lines of evidence demonstrated that cell exposure to TZD generated oxidative stress which dramatically impacted cell survival (14). We tested whether $\triangle$ Pio treatment involved the production of ROS and RNS in colorectal cells. Fluorescent probes, i.e. DCF-DA and
DAF-2DA for ROS and RNS detection, respectively, were used to quantify any changes in the levels of reactive species after HT29 cell exposure to $\triangle$ Pio over $24 \mathrm{~h}$. ROS levels reached a peak 15 min after drug treatment (Fig. 4A). ROS levels were markedly increased with the maximum reached at $8 \mathrm{~h}$ and it decreased slightly over 24 h (Fig. 4B). Similarly, we evaluated ROS level after cell exposure to Pio. In Pio-treated cells, ROS level stayed constant over two hours, then decreased to a level lower than ROS content in DMSO-treated cells (Fig. 4B). When HCT116 cells were tested, ROS levels were increased after a 10-min drug treatment (Fig. 4C), but they stayed mostly constant over the experimental duration whatever the molecule tested (Fig. 4D). Since mitochondria are the main source of radical species and notably superoxide anion radical, colorectal cells were treated in the presence of CCCP together with $\triangle$ Pio and Pio then loaded with DCF-DA (Table II). CCCP pre-treatment inhibited mostly Pio or $\triangle \mathrm{Pio}$-mediated production of ROS in HCT116 cells and to a lesser extent in HT29 cells, supporting the finding that part of the redox alteration was associated with the mitochondria. Moreover, pre-treatment with ascorbic acid or NAC (as antioxidants) prevented or limited the formation of reactive species in colorectal cells (Table II). When cells were treated over three days with $\Delta$ Pio or Pio together with $1 \mathrm{mM}$ ascorbic acid, cell growth was partially restored, suggesting that cell growth arrest was associated to the production of excessive ROS (Fig. 5A and B, respectively). We used ascorbic acid instead of NAC since we observed that $5 \mathrm{mM}$ NAC treatment inhibited cell growth as reported by others (15). Using DAF-2DA, we demonstrated that RNS were present within HT29 cells. The production reached a maximum after $6 \mathrm{~h}$ and stayed constant thereafter (Fig. 6). Of note, the effect of $\Delta$ Pio on RNS production was greater than Pio treatment in HT29. RNS production was increased in HCT116 cells exposed to each molecule after $2 \mathrm{~h}$, but RNS levels stayed almost constant over the experiment duration (Fig. 6B). The results obtained were associated with the increase of iNOS level in both cell lines (Fig. 6C). In fact, HCT116 cells expressed iNOS constitutively whereas the expression of iNOS is inducible in HT29 cells. Nevertheless, our results suggested that RNS were produced in our cell 
A

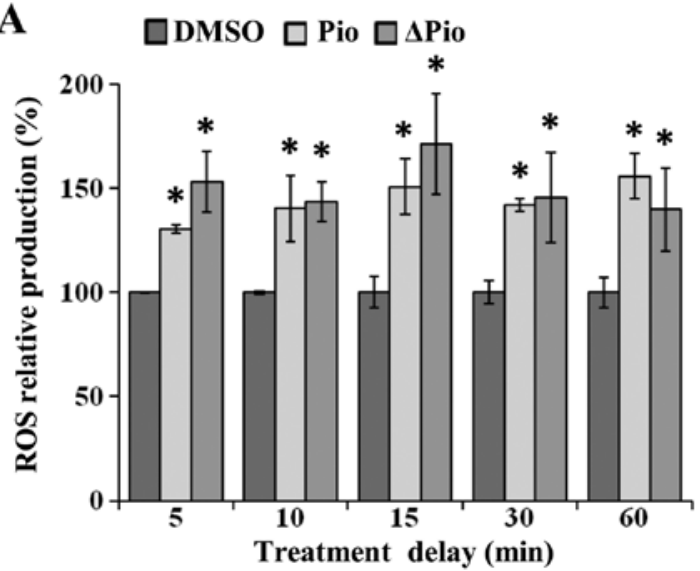

C

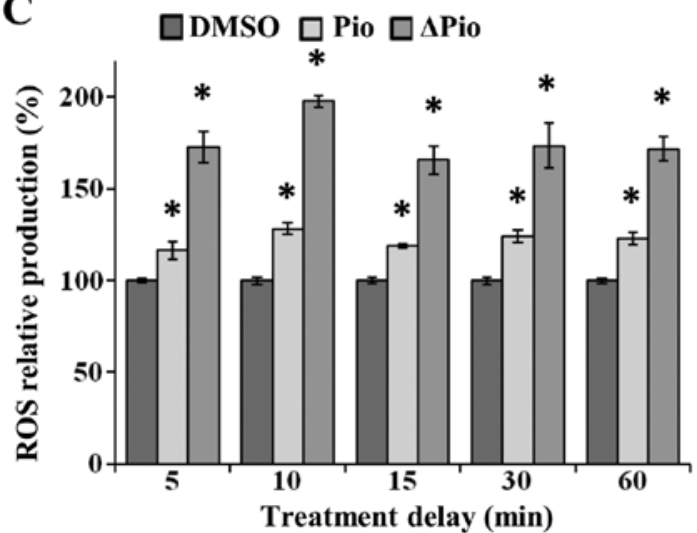

B

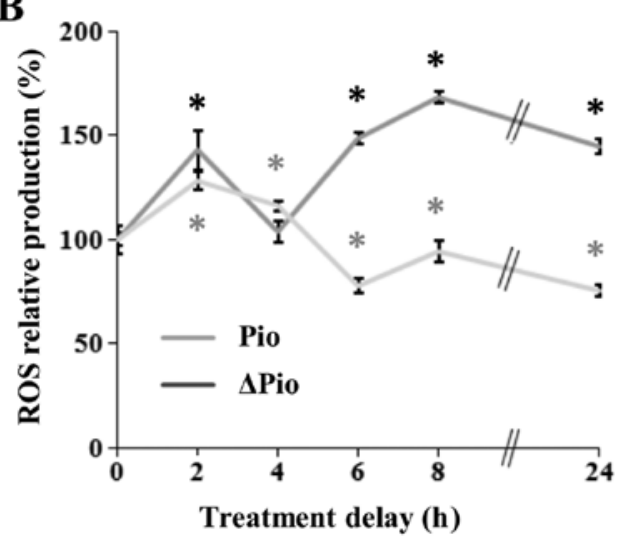

D

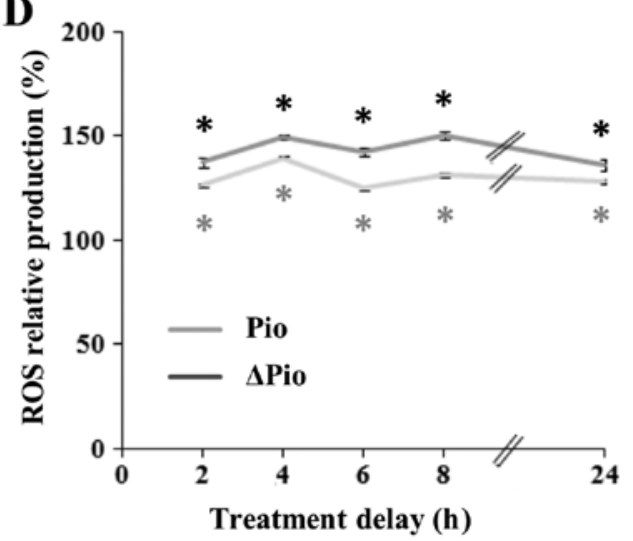

Figure 4. Reactive oxygen-derived species in cell treated with $\Delta 2$-pioglitazone (A-D) HT29 (A and B) or HCT116 cells (C and D) were exposed to $50 \mu \mathrm{M}$ $\Delta 2$-pioglitazone ( $\triangle \mathrm{Pio}$ ) and $50 \mu \mathrm{M}$ pioglitazone (Pio) for various times up to $24 \mathrm{~h}$. ROS productions were quantified after cell loading with DCF-DA. "P $<0.05$, relative to DMSO-treated cells (Student's t-test). Results are means \pm SEM of triplicate determinations from three independent experiments.

Table II. Impact of antioxidants and CCCP on ROS production.

\begin{tabular}{lrr}
\hline Treatment & HT29 & HCT116 \\
\hline Control $[0.1 \%(\mathrm{v} / \mathrm{v}) \mathrm{DMSO}]$ & $100.0 \pm 9.2$ & $100.0 \pm 2.8$ \\
$\Delta$-pioglitazone $(50 \mu \mathrm{M})$ & $171.8 \pm 6.0^{\mathrm{a}}$ & $171.8 \pm 6.0^{\mathrm{a}}$ \\
$\Delta$-pioglitazone $(50 \mu \mathrm{M})+\mathrm{N}$-acetyl cysteine $(5 \mathrm{mM})$ & $117.1 \pm 9.0^{\mathrm{b}}$ & $134.5 \pm 3.2^{\mathrm{b}}$ \\
$\Delta$-pioglitazone $(50 \mu \mathrm{M})+$ ascorbic acid $(1 \mathrm{mM})$ & $123.4 \pm 9.0^{\mathrm{b}}$ & $139.5 \pm 2.6^{\mathrm{b}}$ \\
Pioglitazone $(50 \mu \mathrm{M})$ & $152.0 \pm 4.2^{\mathrm{a}}$ & $122.0 \pm 4.2^{\mathrm{a}}$ \\
Pioglitazone $(50 \mu \mathrm{M})+\mathrm{N}$-acetyl cysteine $(5 \mathrm{mM})$ & $95.7 \pm 9.4^{\mathrm{b}}$ & $94.4 \pm 4.5^{\mathrm{b}}$ \\
Pioglitazone $(50 \mu \mathrm{M})+$ ascorbic acid $(50 \mu \mathrm{M})$ & $103.2 \pm 2.7^{\mathrm{b}}$ & $97.5 \pm 5.4^{\mathrm{b}}$ \\
Control $(0.1 \%(\mathrm{v} / \mathrm{v})$ DMSO) & $100.0 \pm 2.5$ & $100.0 \pm 1.7$ \\
$\Delta$-pioglitazone $(50 \mu \mathrm{M})$ & $159.3 \pm 2.2^{\mathrm{a}}$ & $159.4 \pm 6.6^{\mathrm{a}}$ \\
CCCP $(50 \mathrm{mM})+\Delta$-pioglitazone $(50 \mu \mathrm{M})$ & $139.3 \pm 2.6^{\mathrm{b}}$ & $117.4 \pm 3.6^{\mathrm{b}}$ \\
Pioglitazone $(50 \mu \mathrm{M})$ & $139.2 \pm 2.9^{\mathrm{a}}$ & $126.7 \pm 1.4^{\mathrm{a}}$ \\
CCCP $(50 \mathrm{mM})+$ pioglitazone $(50 \mu \mathrm{M})$ & $108.4 \pm 1.6^{\mathrm{b}}$ & $94.3 \pm 4.5^{\mathrm{b}}$
\end{tabular}

${ }^{a} \mathrm{P}<0.05$ relative to control DMSO-treated cells (Student's t-test); ${ }^{\mathrm{P}}<0.05$ relative to $\Delta \mathrm{Pio}$ or Pio-treated cells (Student's t-test); results are means \pm SEM of triplicate determinations from three independent experiments.

models. The production of an excess of reactive species has been associated to the depletion of intracellular GSH content (14). As demonstrated in Fig. 7, GSH level was decreased in a time-dependent manner over $24 \mathrm{~h}$. They were estimated at $30-50 \%$ when colorectal cells were treated with $\Delta \mathrm{Pio}$ or Pio for $24 \mathrm{~h}$ (Fig. 7A and 7B), respectively. 

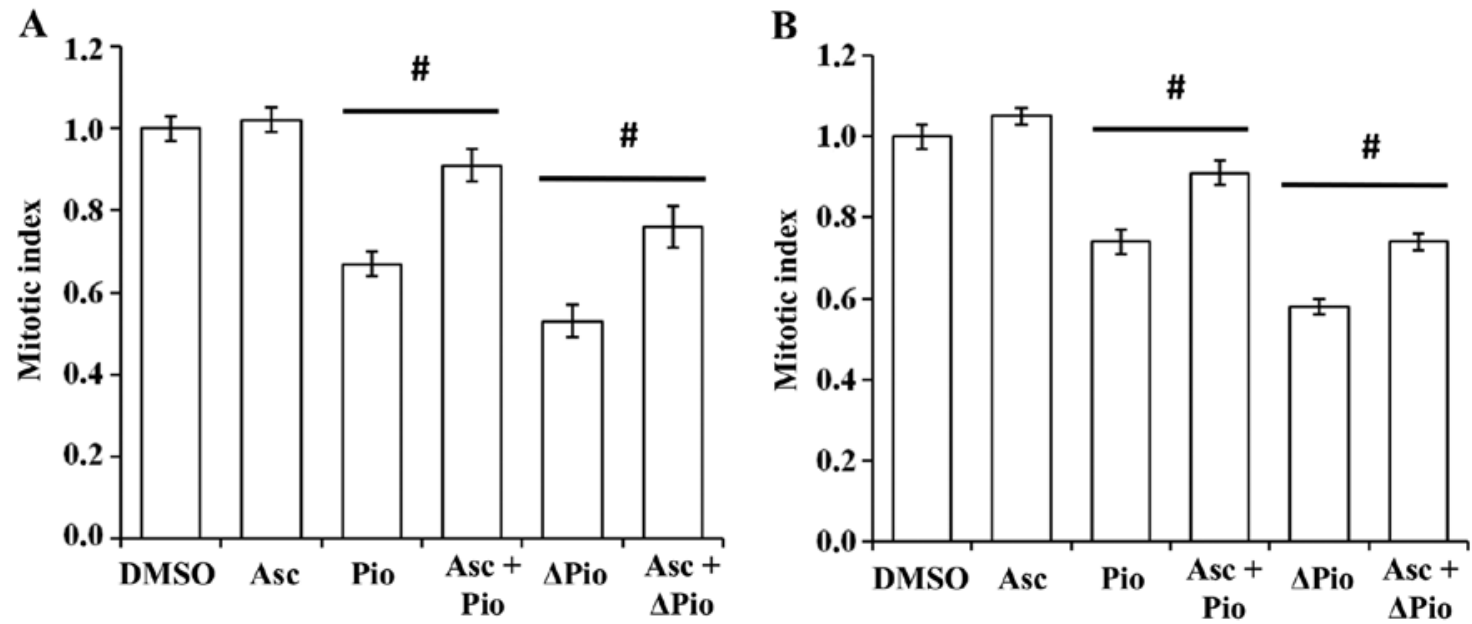

Figure 5. Effect of ascorbic acid pre-treatment on $\Delta 2$-pioglitazone-mediated cell growth inhibition. HT29 (A) or HCT116 cells (B) were treated in the presence of $1 \mathrm{mM}$ ascorbic acid before addition of $50 \mu \mathrm{M} \Delta 2$-pioglitazone ( $\Delta \mathrm{Pio}$ ) or $50 \mu \mathrm{M}$ pioglitazone (Pio) for three days. Cells were harvested and counted. "P $<0.05$, relative to DMSO-treated cells (Student's t-test). Results are means \pm SEM of triplicate numerations from three independent experiments.

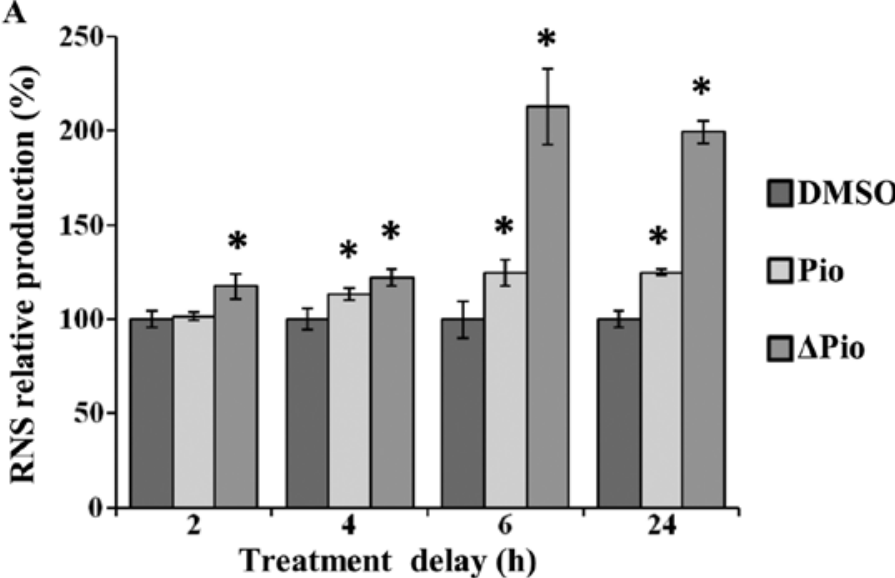

C

HT29

\begin{tabular}{lcc}
\hline DMSO & Pio & $\Delta$ Pio \\
&
\end{tabular}

B

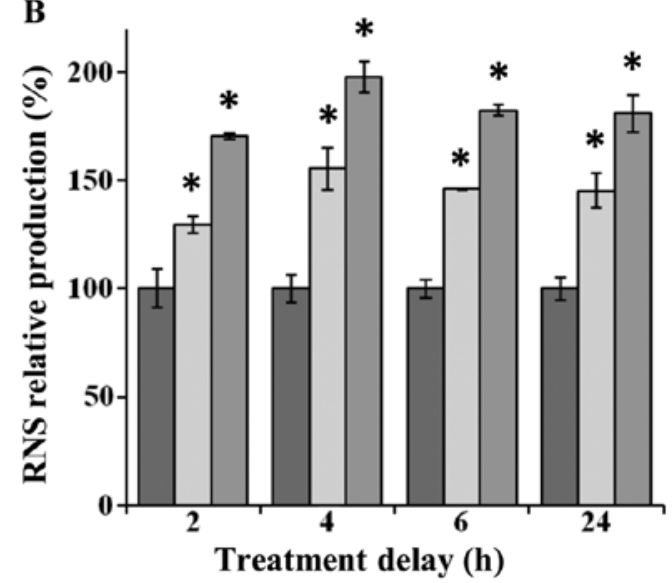

HCT116

\begin{tabular}{lll}
\hline DMSO & Pio & $\Delta$ Pio \\
\hline
\end{tabular}

GAPDH

Figure 6. Reactive nitric oxide derived species in cells exposed to $\Delta 2$-pioglitazone. (A and B) RNS production was quantified after cell loading with DAF-2DA in HT29 (A) and HCT116 cells (B) exposed to $50 \mu \mathrm{M}$ pioglitazone (Pio) and $50 \mu \mathrm{M} \Delta 2$-pioglitazone ( $\Delta$ Pio) for various times up to 24 h. ${ }^{*} \mathrm{P}<0.05$ relative to DMSO-treated cells (Student's t-test). Results are means \pm SEM of triplicate determinations from three independent experiments. (C) Western blotting was performed with protein homogenates $(25 \mu \mathrm{g})$ prepared from HT29 or HCT116 cells exposed for $24 \mathrm{~h}$ to $50 \mu \mathrm{M} \Delta 2-$ pioglitazone $(\Delta \mathrm{Pio})$ and $50 \mu \mathrm{M}$ pioglitazone (Pio) or 0.1\% (v/v) DMSO used as diluent of each drug. Blots were incubated with diluted antibodies against human iNOS (1:500). Mouse anti-human GAPDH antibody $(1: 10,000)$ was used as a marker of sample loading. The results represent one out of three independent experiments.

Induction of autophagy process. Among the mechanisms related to the generation of oxidative stress and involved in cell growth arrest or survival, we studied whether $\Delta$ Pio treatment could induce autophagy. The formation of acidic vesicles was analysed by acridine orange red-fluorescence detection by FACS (Fig. 8A and B). The increase of red-fluorescence due to the acidic vesicles was time-dependent and $\Delta \mathrm{Pio}$ treatment had a greater effect as compared to cells exposed to Pio. Beclin-1, a marker of autophagosome formation, was induced after cell exposure to $\Delta$ Pio or Pio for 3 days whatever the cell line tested (Fig. $8 \mathrm{C}$ and D). Treatment with $\Delta$ Pio had a more pronounced effect when compared to cells exposed to Pio. NAC pre-treatment lowered Beclin-1 expression confirming that autophagy was associated to drug-mediated oxidative stress in both cell lines (Fig. 8E and F). However, NAC treatment did not rescue completely the effect of $\Delta \mathrm{Pio}$ over three days. 

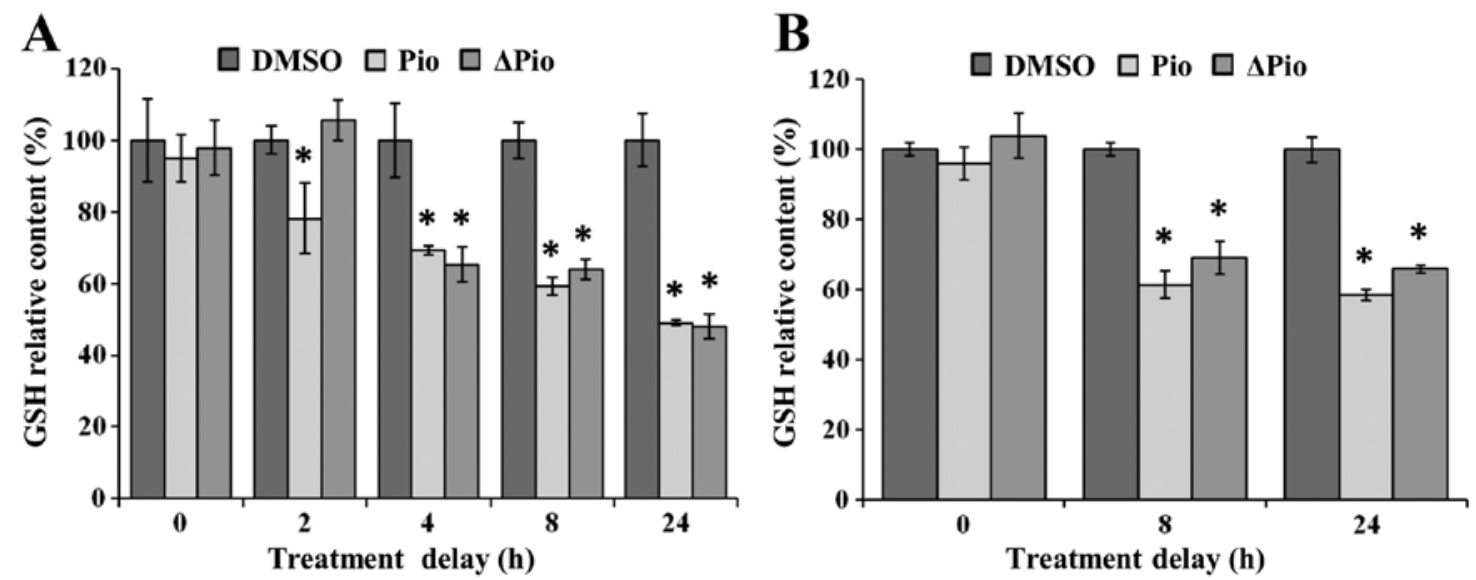

Figure 7. Intracellular glutathione content in colorectal cells during $\Delta 2$-pioglitazone treatment. (A and B) Time course of intracellular glutathione (GSH) content during HT29 (A) or HCT116 (B) cell exposure to $50 \mu \mathrm{M} \Delta 2$-pioglitazone ( $\Delta$ Pio) or $50 \mu \mathrm{M}$ pioglitazone (Pio) over $24 \mathrm{~h}$. "P<0.05 relative to DMSOtreated cells (Student's t-test). Results are means \pm SEM of triplicate determinations from three independent experiments.
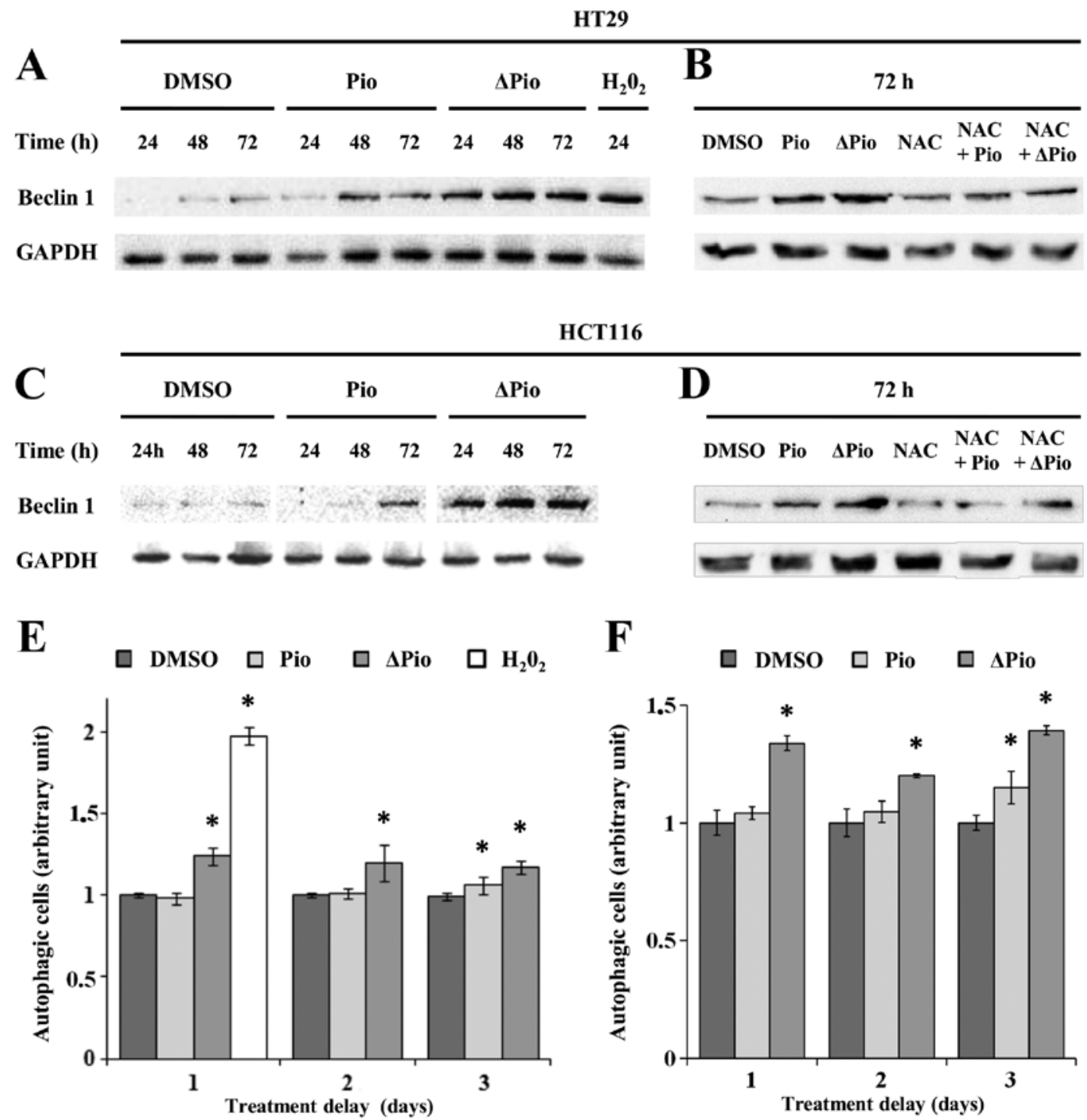

Figure 8. The autophagy process in HT29 and HCT116 cells exposed to $\Delta 2$-pioglitazone. (A-D) HT29 (A) and HCT116 (C) cells were exposed to $50 \mu$ M pioglitazone (Pio) or $50 \mu \mathrm{M} \Delta 2$-pioglitazone ( $\Delta \mathrm{Pio}$ ) over three days. Cells were treated with $\Delta \mathrm{Pio}$ or Pio together with $5 \mathrm{mM} \mathrm{N}$-acetyl cysteine (NAC) for three days (B and D). Western blotting using protein homogenates $(25 \mu \mathrm{g})$ was performed from drug and DMSO-treated cells. Blots were incubated with rabbit antibody against human Beclin-1 (1:1,000). Mouse anti-human GAPDH antibody $(1: 10,000)$ was used as a marker of sample loading. The results represent one out three independent experiments. (E and F) In parallel, acidic vesicles were quantified within HT29 (E) or HCT116 cells (F) by FACS (FL3). Cell treatment with $500 \mu \mathrm{M}$ hydrogen peroxide $\left(\mathrm{H}_{2} \mathrm{O}_{2}\right)$ was used as a positive control. ${ }^{*} \mathrm{P}<0.05$ relative to DMSO-treated cells (Student's t-test). Results are means $\pm \mathrm{SEM}$ of triplicate determinations from three independent experiments. 
A

HT29

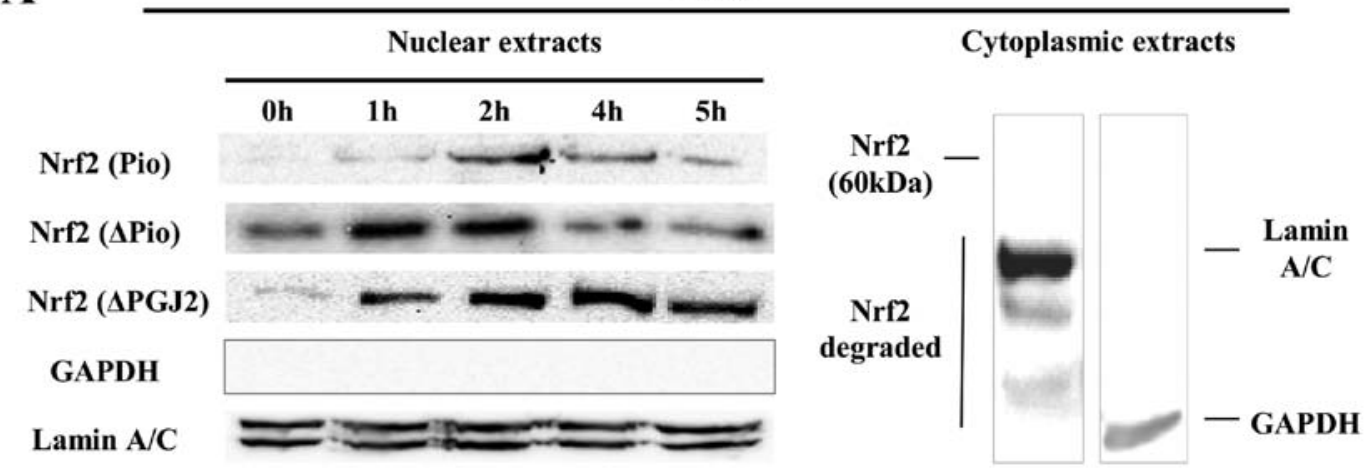

B

HCT116

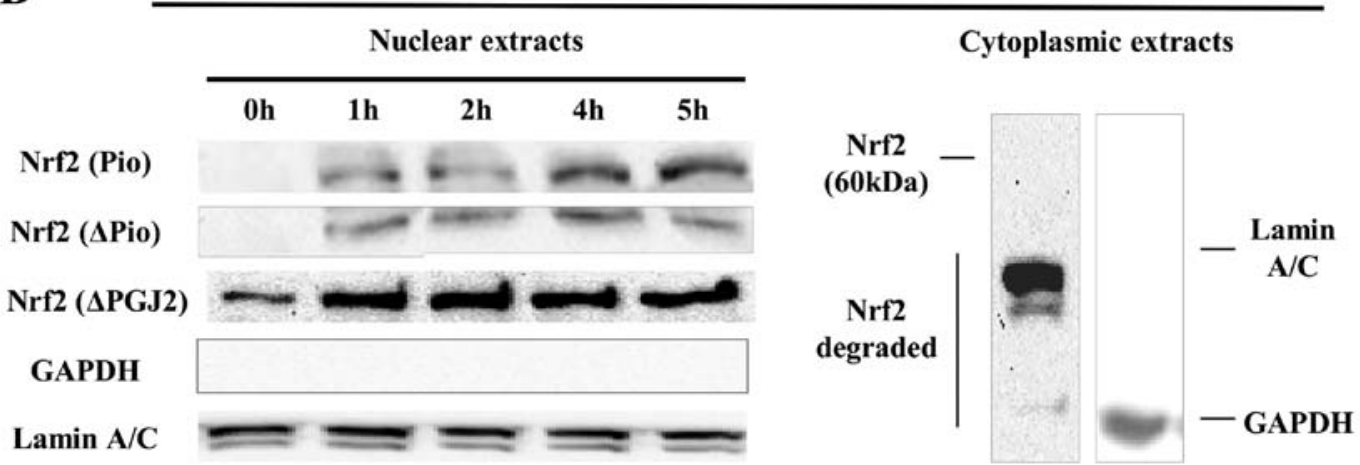

Figure 9. Nrf-2 translocation in the nucleus in $\Delta 2$-pioglitazone-treated cells. (A and B) HT29 (A) and HCT116 cells (B) were treated with $50 \mu \mathrm{M} \Delta 2$-pioglitazone ( $\Delta \mathrm{Pio}$ ), $50 \mu \mathrm{M}$ pioglitazone (Pio) or $3 \mu \mathrm{M}$ 15-deoxy- $\Delta^{12,14}$-prostaglandin $\mathrm{J}_{2}(\Delta \mathrm{PGJ}$ ) for various incubation times up to 5 hours. Western blotting for Nrf-2 (estimated band at $70 \mathrm{kDa}$, diluted antibodies at 1:100) was performed with $20 \mu \mathrm{g}$ nuclear or $50 \mu \mathrm{g}$ cytoplasmic protein homogenates. GAPDH and lamin A/C were, respectively, tested as cytoplasmic and nuclear markers. GAPDH $(1: 10,000)$ or lamin A/C $(1: 500)$ immunodetection was performed in cytoplasmic extracts prepared from unstimulated cells. Results shown are representative of one out of three independent experiments.

Nrf2/Keapl pathway activation. Activation of the Nrf2/Keap1 pathway is associated with redox changes within cells (7). We studied whether $\Delta$ Pio treatment activated translocation of Nrf2 in the cell nuclei. These results were compared to those obtained after cell exposure to $\triangle \mathrm{PGJ} 2$, known as a potent inducer of the Nrf2/Keap1 pathway (16) and the endogenous ligand of PPAR $\gamma$ (17). However, the molecule has been shown to induce apoptosis at a concentration higher than $10 \mu \mathrm{M}$ in colorectal cells (18) but also in cells from other tissue origins (19). We assessed whether cell exposure to $3 \mu \mathrm{M} \Delta \mathrm{PGJ} 2$ had any impact on colorectal cell growth and we showed that $\Delta \mathrm{PGJ} 2$ treatment did not trigger cells to enter apoptosis (Fig. 3). As demonstrated by western blots performed with nuclear extracts, $3 \mu \mathrm{M} \Delta \mathrm{PGJ} 2$ treatment enhanced dramatically Nrf2 nuclear translocation in both cell lines throughout the experiment (Fig. 9). $\triangle \mathrm{PGJ} 2$ treatment enhanced HO-1, a Nrf2 target gene, at the protein level (Fig. 10C and F, respectively). Maximum HO-1 levels were achieved when HCT116 cells are exposed to $\triangle \mathrm{PGJ} 2$ (25 times induction) for $24 \mathrm{~h}$, as compared to that found in HT29 cells (4.7 times induction). Similarly, NQO1 was detected in HT29 and HCT16 cells and the protein levels were increased after cell exposure to $\triangle \mathrm{PGJ} 2$. Moreover, GCL protein contents were also enhanced in $\triangle \mathrm{PGJ}$-treated cells and it was associated with the increase of intracellular GSH levels starting $8 \mathrm{~h}$ after cell treatment (Table III). Addition of BSO, a specific inhibitor of GCL activity, abrogated $\triangle \mathrm{PGJ} 2$
Table III. Intracellular GSH level in $\Delta \mathrm{PGJ}_{2}$-treated cells.

\begin{tabular}{lcc}
\hline Treatment & HT29 & HCT116 \\
\hline DMSO $[0.1 \%(\mathrm{v} / \mathrm{v})], 4 \mathrm{~h}$ & $100.0 \pm 3.9$ & - \\
$\Delta \mathrm{PGJ} 2(3 \mu \mathrm{M}), 4 \mathrm{~h}$ & $93.6 \pm 3.9$ & - \\
Vehicle, $8 \mathrm{~h}$ & $100.0 \pm 5.0$ & $100.0 \pm 1.9$ \\
$\Delta \mathrm{PGJ} 2(3 \mu \mathrm{M}), 8 \mathrm{~h}$ & $168.1 \pm 6.9^{\mathrm{a}}$ & $171.8 \pm 2.1^{\mathrm{a}}$ \\
Vehicle, $24 \mathrm{~h}$ & $100.0 \pm 7.4$ & $100.0 \pm 3.6$ \\
$\Delta \mathrm{PGJ} 2(3 \mu \mathrm{M}), 24 \mathrm{~h}$ & $134.1 \pm 5.8^{\mathrm{a}}$ & $202.9 \pm 3.6^{\mathrm{a}}$ \\
$\Delta \mathrm{PGJ} 2(3 \mu \mathrm{M})+\mathrm{L}-\mathrm{buthionine}-$ & $6.8 \pm 0.2^{\mathrm{b}}$ & $16.9 \pm 1.0^{\mathrm{b}}$ \\
$(\mathrm{S}-\mathrm{R})$ sulfoximine $(100 \mu \mathrm{M})$ & & \\
\hline
\end{tabular}

${ }^{\mathrm{a}} \mathrm{P}<0.05$ relative to DMSO-treated cells (Student's $\mathrm{t}$-test); ${ }^{\mathrm{b}} \mathrm{P}<0.05$ relative to $\triangle \mathrm{PGJ} 2$-treated cells (Student's t-test); results are means \pm SEM of triplicate determinations from three independent experiments (vehicle, $0.1 \%$ DMSO).

mediated GSH synthesis. Thus, at the dose used $\triangle \mathrm{PGJ} 2 \mathrm{had}$ a protective effect on colorectal cells. As shown in Fig. 9, Nrf2 accumulated in cell nuclei from $\Delta$ Pio or Pio-treated cells but differences existed depending on the cell line tested. In HT29 cells, maximum Nrf2 nuclear levels were found at $1 \mathrm{~h}$ in 
HT29
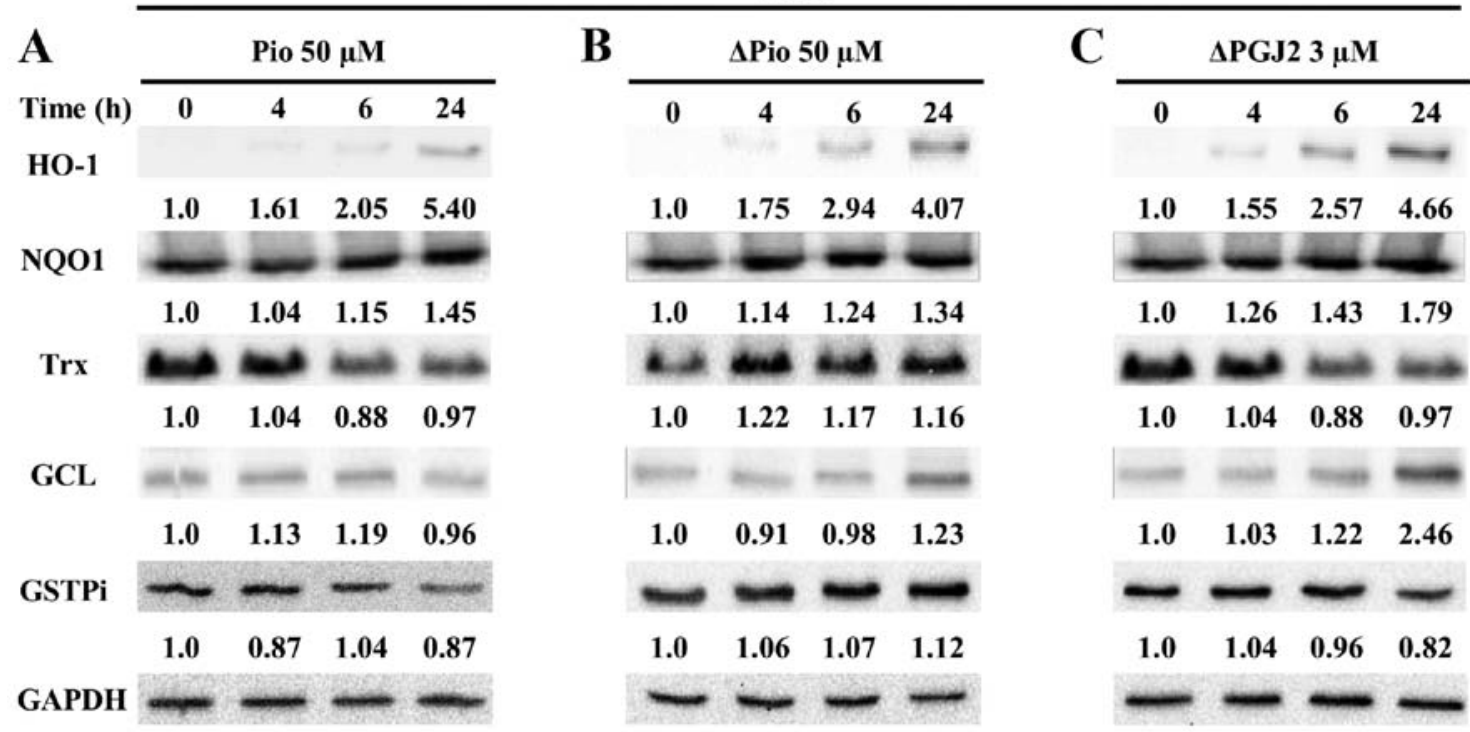

HCT116
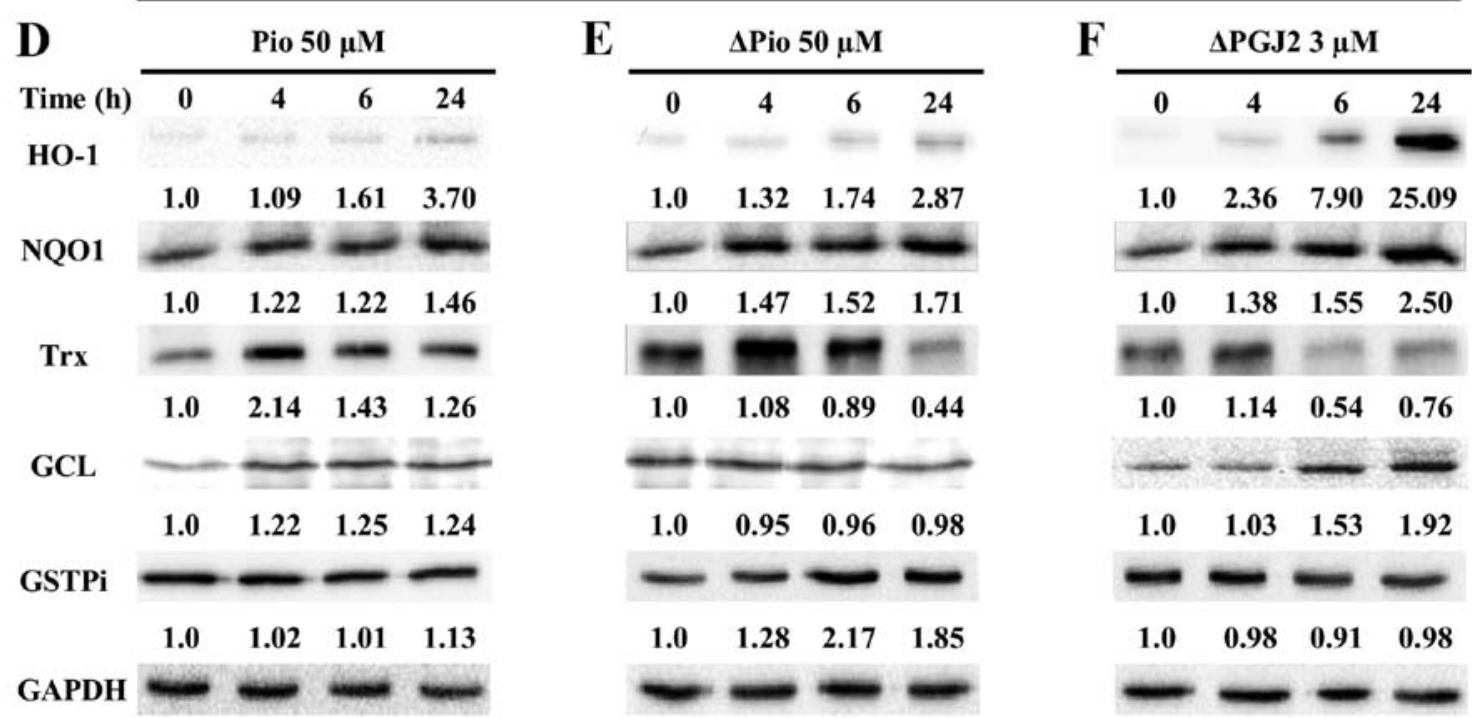

Figure 10. Expression of Nrf2 target gene in colorectal cells exposed to pioglitazone, $\Delta 2$-pioglitazone or $\Delta$ PGJ2. (A-F) HT29 cells (A-C) and HCT116 cells (D-F) were treated with $50 \mu \mathrm{M}$ pioglitazone (Pio; A and D), $50 \mu \mathrm{M} \Delta 2$-pioglitazone ( $\Delta$ Pio; B and E) or $3 \mu \mathrm{M}$ 15-deoxy- $\Delta^{12,14}$-prostaglandin J2 ( $\Delta$ PGJ2; $\mathrm{C}$ and $\mathrm{F}$ ) for various incubation times. Western blotting was performed as described in Materials and methods using, respective, mouse or rabbit diluted antibodies against HO-1 (1:1,000), NQO1 (1:1,000), Trx (1:1,000), GCL (1:500) and GSTPi (1:500). Each blot was stripped in order to detect human GAPDH $(1: 10,000)$. Bands were quantified and normalized to GAPDH content. The ratio, level of protein of interest versus GAPDH content, in DMSO-treated cells was considered as 1.00. Results shown are representative of one out of three independent experiments.

$\Delta$ Pio-treated cells and at $2 \mathrm{~h}$ in Pio-treated cells (Fig. 9A). In contrast, Nrf2 translocation began $1 \mathrm{~h}$ after the HCT116 cell exposure to each drug and it stayed mostly constant during the experiment duration (Fig. 9B). We analysed which Nrf2 target gene could be activated during drug treatment. Whatever the cell line tested, HO-1 expression was induced demonstrating that $\mathrm{HO}-1$ was involved in $\Delta$ Pio-mediated oxidative stress. $\Delta$ Pio or Pio-treatment increased HO-1 expression to a similar level whatever the cell tested (Fig. 10A,B and D,E respectively). Focusing on known Nrf2 target genes such as NQO1, GSTPi, thioredoxin and GCL, respective protein levels depended on the cell line tested and the treatment applied. NQO1 expression was increased at the protein levels, in Pio (Fig. 10A,D) and $\Delta$ Pio treated cells (Fig. 10B,E). There were only small changes in GCL levels in Pio and $\triangle$ Pio-treated HT29 or HCT116 cells (Fig. 10A,B and D,E respectively). GSTPi expression did not change dramatically upon molecule treatment whatever the cell line tested. Trx levels rose to a maximum after HCT116 cell exposure to Pio for $4 \mathrm{~h}$ (Fig. 10D), whereas its expression was often decreased in the other treatment conditions. Thus, activation of the Nrf2 pathway correlated well to an increase of reactive species production within the cells.

HO-1 expression in the presence of antioxidant. HO-1 expression is enhanced in stressed cells but its expression depends also on activation of diverse transduction pathways or a mechanism involving GSH depletion (7). Based on our 
A

HT29

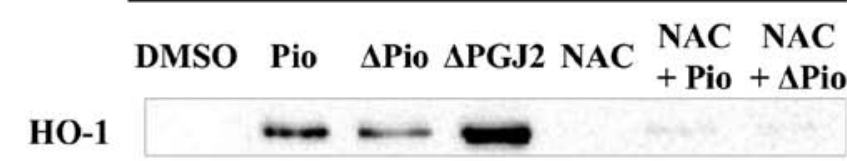

GAPDH
B

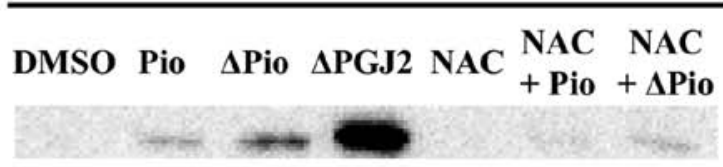

Figure 11. Impact of N-acetyl cysteine on $\Delta$ 2-pioglitazone or pioglitazone-mediated HO-1 expression. HT29 (A) and HCT116 (B) cells were treated with $50 \mu \mathrm{M}$ pioglitazone (Pio) or $50 \mu \mathrm{M} \Delta 2$-pioglitazone $(\Delta \mathrm{Pio})$ for $24 \mathrm{~h}$, in the presence or absence of $5 \mathrm{mM} \mathrm{N}$-acetyl cysteine ( $\mathrm{NAC}$ ). Cell treatment with $3 \mu \mathrm{M}$ 15-deoxy- $\Delta^{12,14}$-prostaglandin $\mathrm{J}_{2}(\Delta \mathrm{PGJ}$ ) for $24 \mathrm{~h}$ was used as an activator of Nrf2 signalling pathway. HO-1 was detected by western blotting (diluted antibodies at 1:1,000) performed with protein homogenates prepared from treated cells. Blots are representative of one out of three independent experiments.

results, notably the presence of reactive species and GSH depletion during $\Delta$ Pio treatment, we assessed whether HO-1 expression could be modulated by antioxidants such as NAC (a thiol scavenger) (Fig. 11). Pre-treatment with NAC prevented the production of ROS within HT29 colorectal cells (Table II) and addition of the antioxidant inhibited almost completely $\Delta$ Pio-induced HO-1 expression (Fig. 11A). These results were close to those obtained when HCT116 cells were tested (Table II and Fig. 11B).

\section{Discussion}

Using a similar experimental approach as described by others (10), we synthesized $\Delta$ Pio, the analogue of Pio, which binds to the PPAR $\gamma$ receptor without activating it (Fig. 1). The molecule was initially used in order to discriminate PPAR $\gamma$-dependent from -independent effects on prostate carcinoma-derived cells (10), but $\Delta$ Pio impact on other cancer-derived cells from other tissue origins had not been tested.

TZD treatment has been shown to limit colorectal cell growth or to trigger cells to enter apoptosis (18). However, several studies have demonstrated that cell exposure to TZD involved unexpected effects different from PPAR $\gamma$-dependent or -independent receptor ligand activation; notably, treatment with TZD generated oxidative stress, which in turn was related to cell growth arrest $(5,20)$. As presented in this report, HT29 or HCT116 cell exposure to $\Delta$ Pio reduced colorectal growth more efficiently than Pio. $\Delta$ Pio treatment induced cell growth arrest, associated with cell accumulation in the G0/G1 phase. In contrast, Pio-treated cells accumulated in S phase (Table I) as previously reported by others (21). The $\Delta$ Pio effect observed could also reflect differentiation-like processes which occur in breast cancer cells exposed to TZD (22). Colorectal cell growth arrest was associated to autophagy initiated by the production of reactive species. Autophagy has been reported in other TZD-treated cells $(23,24)$ but the phenomenon is related to either dependent or independent activation of PPAR $\gamma$. In breast cancer cells, TZD-dependent receptor activation induced autophagy through $\mathrm{HiF} 1 \alpha$ activation (24). Autophagy processes were described in neuroblastoma cells exposed to $\triangle \mathrm{PGJ} 2$, the endogenous ligand of PPAR $\gamma$ when cells were grown in standard conditions (25). In contrast, cells underwent apoptosis in medium supplemented with de-lipidated serum (25). Similarly, absence of fetal calf serum potentiated TZD-mediated colorectal cell growth arrest and apoptosis, whereas supplementation with serum had no consequence on cell survival when cells were treated with $\triangle \mathrm{PGJ} 2$ or TZD (18). On the other hand, it has been hypothesised that the Nrf2/Keap1 pathway was activated either to contribute to cell growth in the presence of oxidative stress (7) or, as suggested by others in another experimental cell model (26), by lowering autophagy processes to promote cell survival. The latter could explain why $\Delta \mathrm{Pio}$ and Pio did not trigger cells to enter apoptosis. Indeed, the absence of apoptotic cell death contrasted to the effect of troglitazone or ciglitazone and respective $\Delta 2$-analogues on prostate carcinoma-derived cells (10).

Several lines of evidence demonstrated that cell exposure to TZD generated oxidative stress which dramatically impacted cell survival. For example, Jurkat or A549 cell exposure to troglitazone lead to the production of an excess of ROS and RNS (14). Similar results were obtained with astrogliomaderived cells exposed to ciglitazone (27). The mitochondrial membrane potential was lost after cell treatment with TZD $(5,14)$. We have shown that HT29 and HCT116 cell exposure to $\Delta$ Pio or Pio involved the production of ROS and RNS which was inhibited by the supplementation of diverse antioxidants (Figs. 4 and 6, Table II). ROS content was enhanced within minutes suggesting that the effect observed was not dependent on PPAR $\gamma$ activation as discussed previously (5). According to previous data, TZD treatment involved alteration of mitochondria function (27). In our cell model, CCCP inhibited mostly $\triangle \mathrm{Pio}$ or Pio-mediated production of ROS confirming alteration at the mitochondrial membrane potential. Moreover, superoxyl was detected using MitoSOX probe (unpublished data). Following TZD treatment and dependent on the human cell model used, it has been shown that intracellular GSH content was decreased $(14,28)$ concomitantly with inhibition of glutathione reductase (28) or with an increase of glutathione peroxidase activities (29). In the latter report, human pluripotent embryonic carcinoma NTERA2/D1 cell exposure to Pio for long-term treatment (several weeks), involved the production of peroxides and the concomitant, but independent, increase of glutathione peroxidase activities (29). However, we failed to demonstrate a significant increase of glutathione peroxidase enzyme activities, while GSH content stayed low in HT29 cells exposed to Pio over five days (unpublished data). We cannot exclude the concept that Pio or $\Delta$ Pio could be conjugated to GSH as demonstrated for $\triangle \mathrm{PGJ} 2$ in hepatoblastoma-derived cells (30). This mechanism leads to drug efflux 
as demonstrated for other xenobiotics (31). However, TZD conjugation to GSH has been reported only in an in vitro assay with microsomal fraction prepared from human or murine hepatocytes (32). Moreover, conjugation of Pio to GSH needs the opening of the thiazolidine ring (33). In the case of $\Delta \mathrm{Pio}$, the conjugation could occur via the double bond adjoining the thiazolidine moiety of the molecule. Such a mechanism could explain the active effect of $\Delta$ Pio on the Nrf2/Keap1 pathway, similar to the action of $\Delta \mathrm{PGJ} 2$ on Keap1. $\Delta \mathrm{PGJ} 2$ reacts via Michaels addition to one of the cysteyl residues of the Nrf2 inhibitor leading to Keap1 release from Nrf2, which in turn undergoes translocation within the cell nucleus. This mechanism was described for 2-cyano-3,12-dioxoolean-1,9dien-28-oic acid (CDDO) referred to as a PPAR $\gamma$ agonist (34). Indeed, the excessive production of ROS or GSH depletion after cell exposure to diverse drugs (7) or nitric oxide (35) involved activation of the Nrf2/Keap1 pathway, but crosstalk exists (36). Interestingly, HO-1 could be notably regulated by PPAR $\gamma$ (37). In our cell model, HO-1 expression was induced with cells exposed to $\triangle \mathrm{Pio}$, the analogue of Pio, supporting that drug effect was not related to PPAR $\gamma$-dependent mechanisms.

Finally, we showed that at a comparable dose $(50 \mu \mathrm{M})$, $\Delta$ Pio and Pio did not have a similar impact on HT29 cells compared to that obtained with HCT116 cells. However, the Pio concentration used was nearly 20 times higher than the serum concentration in human after an oral administration of $30 \mathrm{mg}$ Pio (5). We could not exclude that the results observed after cell exposure to $\Delta$ Pio reflected similar effects on cell redox alteration as those obtained with Pio.

\section{Acknowledgements}

We thank Dr Eric Battaglia and Professor Denyse Bagrel for discussion and reading of the manuscript and Professor S.N. Thornton for correcting the English. This study was supported by grants from la Ligue Contre le Cancer. Sophie Huber obtained financial support from Ministère de la Recherche et de la Technologie. Sergio Valente was granted from Marie Curie Initial Training Network (ITN) in the FP7 People Programme - Natural Products and related Redox Catalysts: Basic Research and Applications in Medicine and Agriculture.

\section{References}

1. Oakes ND, Camilleri S, Furler SM, Chisholm DJ and Kraegen EW: The insulin sensitizer, BRL 49653, reduces systemic fatty acid supply and utilization and tissue lipid availability in the rat. Metabolism 46: 935-942, 1997.

2. Michalik L, Desvergne B and Wahli W: Peroxisome-proliferatoractivated receptors and cancers: complex stories. Nat Rev Cancer 4: 61-70, 2004

3. Koeffler HP: Peroxisome proliferator-activated receptor gamma and cancers. Clin Cancer Res 9: 1-9, 2003.

4. Castrillo A, Diaz-Guerra M, Hortelano S, Martin-Sanz P and Bosca L: Inhibition of I $\mathrm{B}$ kinase and I $\mathrm{B}$ phosphorylation by 15-deoxy $\Delta^{12-14}$-prostaglandin $\mathrm{J}_{2}$ in activated murine macrophages. Mol Cel Biol 20: 1692-1698, 2000

5. Feinstein D, Spagnolo A, Akar C, Weinberg G, Murphy P, Gavrilyuk V, et al: Receptor-independent actions of PPAR thiazolidinedione agonists: Is mitochondrial function the key? Biochem Pharmacol 2005: 177-188, 2005.

6. Wei S, Yang J, Lee SL, Kulp SK and Chen CS: PPARgammaindependent antitumor effects of thiazolidinediones. Cancer Lett 276: 119-124, 2009.
7. Niture SK, Kaspar JW, Shen J and Jaiswal AK: Nrf2 signaling and cell survival. Toxicol Appl Pharmacol 244: 37-42, 2009.

8. Gong P, Stewart D, Hu B, Li N, Cook J, Nel A, et al: Activation of the mouse heme oxygenase-1 gene by 15 -deoxy-Delta $(12,14)$ prostaglandin $\mathrm{J}(2)$ is mediated by the stress response elements and transcription factor Nrf2. Antioxid Redox Signal 4: 249-257, 2002.

9. Palakurthi SS, Aktas H, Grubissich LM, Mortensen RM and Halperin JA: Anticancer effects of thiazolidinediones are independent of peroxisome proliferator-activated receptor gamma and mediated by inhibition of translation initiation. Cancer Res 61: 6213-6218, 2001.

10. Shiau C, Yang C, Kulp S, Chen K, Chen C, Huang J, et al: Thiazolidinediones mediate apoptosis in prostate cancer cells in part through inhibition of $\mathrm{Bcl}-\mathrm{xL} / \mathrm{Bcl}-2$ functions independently of PPAR $\gamma$. Cancer Res 65: 1561-1569, 2005.

11. Sohda T, Momose Y, Meguro K, Kawamatsu Y, Sugiyama Y and Ikeda H: Studies on antidiabetic agents. Synthesis and hypoglycemic activity of 5-[4-(pyridylalkoxy)-benzyl]-2,4-thiazolidinediones. Arzneim Forsch 40: 37-42, 1990.

12. Deguest G, Bischoff L, Fruit L and Marsais F: Anionic, in situ generation of formaldehyde: a very useful and versatile tool in synthesis. Org Lett 9: 1165-1167, 2007.

13. Lenton $\mathrm{K}$, Therriault $\mathrm{H}$ and Wagner J: Analysis of glutathione and glutathione disulfide in whole cells and mitochondria by postcolumn derivatization high-performance liquid chromatography with ortho-phthaladehyde. Anal Biochem 274: 125-130, 1999.

14. Atarod EB and Kehrer JP: Dissociation of oxidant production by peroxisome proliferator-activated receptor ligands from cell death in human cell lines. Free Radic Biol Med 37: 36-47, 2004.

15. Liu M, Wikonkal NM and Brash DE: Induction of cyclindependent kinase inhibitors and $\mathrm{G}(1)$ prolongation by the chemopreventive agent $\mathrm{N}$-acetylcysteine. Carcinogenesis 20: 1869-1872, 1999 .

16. Uchida K and Shibata T: $15-D e o x y-D e l t a(12,14)$-prostaglandin $\mathbf{J}_{2}$ : an electrophilic trigger of cellular responses. Chem Res Toxicol 21: 138-144, 2008.

17. Kliewer SA: A prostaglandin $\mathrm{J}_{2}$ metabolite binds peroxisome proliferator-activated receptor gamma and promotes adipocyte differentiation. Cell 83: 813-819, 1995.

18. Shimada T, Kojima K, Yoshiura K, Hiraishi H and Terano A: Characteristics of the peroxisome proliferator activated receptor gamma (PPARgamma) ligand induced apoptosis in colon cancer cells. Gut 50: 658-664, 2002.

19. Levonen AL, Dickinson DA, Moellering DR, Mulcahy RT, Forman HJ and Darley-Usmar VM: Biphasic effects of 15-deoxydelta(12,14)-prostaglandin $\mathrm{J}(2)$ on glutathione induction and apoptosis in human endothelial cells. Arterioscler Thromb Vasc Biol 21: 1846-1851, 2001.

20. Polvani S, Tarocchi M and Galli A: PPARgamma and oxidative stress: Con(beta) catenating NRF2 and FOXO. PPAR Res 2012: 641087, 2012

21. Schaefer KL, Takahashi H, Morales VM, Harris G, Barton S, Osawa E, et al: PPARgamma inhibitors reduce tubulin protein levels by a PPARgamma, PPARdelta and proteasome-independent mechanism, resulting in cell cycle arrest, apoptosis and reduced metastasis of colorectal carcinoma cells. Int J Cancer 120: 702-713, 2007.

22. Mueller E, Sarraf P, Tontonoz P, Evans RM, Martin KJ, Fletcher $\mathrm{M}$, et al: Terminal differentiation of human breast cancer through PPAR $\gamma$. Mol Cell 1: 465-470, 1998.

23. Cerquetti L, Sampaoli C, Amendola D, Bucci B, Masuelli L, Marchese R, et al: Rosiglitazone induces autophagy in H295R and cell cycle deregulation in SW13 adrenocortical cancer cells. Exp Cell Res 317: 1397-1410, 2011.

24. Zhou J, Zhang W, Liang B, Casimiro MC, Whitaker-Menezes D, Wang M, et al: PPARgamma activation induces autophagy in breast cancer cells. Int J Biochem Cell Biol 41: 2334-2342, 2009.

25. Rodway HA, Hunt AN, Kohler JA, Postle AD and Lillycrop KA: Lysophosphatidic acid attenuates the cytotoxic effects and degree of peroxisome proliferator-activated receptor gamma activation induced by 15 -deoxyDelta ${ }^{12,14}$-prostaglandin $\mathrm{J}_{2}$ in neuroblastoma cells. Biochem J 382: 83-91, 2004.

26. Rao VA, Klein SR, Bonar SJ, Zielonka J, Mizuno N, Dickey JS, et al: The antioxidant transcription factor $\mathrm{Nrf} 2$ negatively regulates autophagy and growth arrest induced by the anticancer redox agent mitoquinone. J Biol Chem 285: 34447-34459, 2010. 
27. Perez-Ortiz JM, Tranque $\mathrm{P}$, Burgos M, Vaquero CF and Llopis $\mathrm{J}$ : Glitazones induce astroglioma cell death by releasing reactive oxygen species from mitochondria: modulation of cytotoxicity by nitric oxide. Mol Pharmacol 72: 407-417, 2007.

28. Kondo M, Oya-Ito T, Kumagai T, Osawa T and Uchida K: Cyclopentone prostaglandins as potential inducers of intracellular oxidative stress. J Biol Chem 276: 12076-12083, 2001.

29. Ghosh S, Patel N, Rahn D, McAllister J, Sadeghi S, Horwitz G, et al: The thiazolidinedione pioglitazone alters mitochondrial function in human neuron-like cells. Mol Pharmacol 71: 1695-1702, 2007.

30. Brunoldi EM, Zanoni G, Vidari G, Sasi S, Freeman ML, Milne GL, et al: Cyclopentenone prostaglandin, 15-deoxyDelta ${ }^{12,14}-\mathrm{PGJ}_{2}$, is metabolized by HepG2 cells via conjugation with glutathione. Chem Res Toxicol 20: 1528-1535, 2007.

31. Wu G, Fang YZ, Yang S, Lupton JR and Turner ND: Glutathione metabolism and its implications for health. J Nutr 134: 489-492, 2004.

32. Alvarez-Sanchez R, Montavon F, Hartung T and Pähler A: Thazolididedione bioactivation: a comparison of the bioactivation potentials of troglitazone, rosiglitazone, and pioglitazone using stable isotope-labeled analogues and liquid chromatography tandem mass spectrophometry. Chem Res Toxicol 16: 1106-1116, 2006
33. Uchiyama M, Fischer T, Mueller J, Oguchi M, Yamamura N, Koda $\mathrm{H}$, et al: Identification of novel metabolic pathways of pioglitazone in hepatocytes: N-glucuronidation of thiazolidinedione ring and sequential ring-opening pathway. Drug Metab Dispos 38: 946-956, 2010.

34. Ferguson HE, Thatcher TH, Olsen KC, Garcia-Bates TM, Baglole CJ, Kottmann RM, et al: Peroxisome proliferatoractivated receptor-gamma ligands induce heme oxygenase-1 in lung fibroblasts by a PPARgamma-independent, glutathionedependent mechanism. Am J Physiol Lung Cell Mol Physiol 297: L912-L919, 2009.

35. Li CQ, Kim MY, Godoy LC, Thiantanawat A, Trudel LJ and Wogan GN: Nitric oxide activation of Keap1/Nrf2 signaling in human colon carcinoma cells. Proc Natl Acad Sci USA 106: 14547-14551, 2009

36. Chia AJ, Goldring CE, Kitteringham NR, Wong SQ, Morgan P and Park BK: Differential effect of covalent protein modification and glutathione depletion on the transcriptional response of $\mathrm{Nrf} 2$ and NF-kappaB. Biochem Pharmacol 80: 410-421, 2010.

37. Kronke G, Kadl A, Ikonomu E, Bluml S, Furnkranz A, Sarembock IJ, et al: Expression of heme oxygenase-1 in human vascular cells is regulated by peroxisome proliferator-activated receptors. Arterioscler Thromb Vasc Biol 27: 1276-1282, 2007. 